\title{
PERLINDUNGAN HUKUM ATAS MEREK TERKENAL
}

\author{
Siti Marwiyah \\ Fakultas Hukum Universitas DR. Soetomo Surabaya \\ Mobile Phone: 08179628845 \\ E-mail:syiety@yahoo.co.id
}

\begin{abstract}
Abstrak
Lamanya waktu yang dibutubkan untuk dapat menjadikan suatu merek menjadi terkenal secara luas dan dipergunakan oleh masyarakat luas, menjadikan beberapa produsen melakukan jalan pintas dengan menjalankan perilaku bisnis curang yaitu dengan melakukan "pembajakan" atau peniruan dari merek yang telah lama beredar di pasaran, atau dapat juga disebut sebagai merek yang sudah terkenal. Pelanggaran merek juga mengkedepan dalam issue pararelimport dimana barang-barang diperoleh dari luar negeri secara sah, kemudian dibawa masuk. ke Indonesia untuk. tujuan komersil tanpa sepengetahuan dan persetujuan pemegang lisensi atas merek tersebut di Indonesia. Dalam hal ini tidak ada pemalsuan merek, tetapi hal ini melanggar hak-bake penerima lisensi, karena merusak pangsa pasarpemegang lisensi. Adanya praktik curang ini, tidak, hanya perusabaan pemilike merek terkenal yang dirugikan akan tetapi masyarakat sebagai konsumen dan negara juga dirugikan. Bagi pemilik merek kerugian yang dirasakan adalah menurunnya pendapatan, dan apabila kualitas dari barang dan jasa yang ditiru lebih rendah, maka akan menurunkan citra produk tersebut di mata konsumen. Bagi konsumen kerugian yang dideritanya adalah mutu barang yang rendah, sedangkan bagi negara kerugian yang timbul adalah berkurangnya penerimaan pajak. Perlindungan bukum yang memadai terbadap merek-merek terkenal, yang kebanyakan adalab merek terkenal dari luar negeri muntlak diperlukan, tanpa mengurangi bak pengusaha pribumi yang memiliki merek yang sama dengan merek terkenal tersebut yang menggunakannya dengan itikad baik. Namun demikian untuk menjaga keseimbangan hak dari pemilik merek terkenal dalam dan luar negeri, perlu juga kiranya dirumuskan kriteria merek terkenal "lokal", yaitu merek terkenal yang berkembang pada suatu daerah atau wilayah tertentu atau merek terkenal yang berada dalam suatu negara

Painstaking efforts and long process to make one product widely popular among the consumers force the producers to take an illegal short cut by doing a piracy or immitating a well-known brand. One typical type of brand violation is a pararel import, in which the products are legally imported and then sold without any prior approval from the licence holder. In this case no brand violation is breached, but this practice violates the right of the licence bolder. The damage is not only done to the the licence holder, but also to the consumers and the importing country. For the licence holder, the practice will significantly reduce the benefit. The lower quality of the illegal product will also contribute to the decreasing image of the original products. This practice will make the consumers unsatisfied, due to the product of lower quality, and it also reduces the revenue for the state. Legal protection for branded product, which are mostly imported, is badly in need, without denying the right of local producers to use the well-known branded in a good intention.
\end{abstract}

\section{Kata Kunci:}




\section{Latar Belakang}

Perusahaan yang memproduksi barang atau jasa untuk memajukanusahanya menggunakan banyak strategi salah satunya dengan menggunakan merek. Merek digunakan untuk memberikan identitas terhadap barang dagangan atau produksi satu perusahaan atau jasa dengan barang atau produksi perusahaan atau jasa lain yang sejenis. Tidak dapat dibayangkan apabila suatu produk barang atau jasa dipasarkan tanpa menggunakan merek. Tentu konsumen sulit untuk membedakan barang atau jasa dari pruduk suatu badan usaha yang satu dengan badan usaha yang lain, disamping itu konsumen juga akan kesulitan untuk memperoleh produk tersebut di pasaran, kecuali diperoleh melalui pembelian langsung di tempat produksinya atau dijajakan langsung oleh produsen kepada konsumen. Karenanya merek merupakan tanda pengenal asal barang dan jasa sekaligus mempunyai fungsi menghubungkan barang dan jasa yang bersangkutan dengan produsennya. Hal itu menggambarkan jaminan kepribadian (individuality), dan reputasi barang dan jasa hasil usahanya tersebut sewaktu diperdagangkan.

Merek dapat pula menjadi asset perusahaan apabila produk barang atau jasa yang dihasilkan dengan menggunakan merek tersebut berhasil menjadi barang atau jasa yang banyak digunakan oleh masyarakat. Maka dari itu merek yang bersangkutan akan menjadi "kata kunci" bagi masyarakat yang akan membeli suatu barang atau jasa. ${ }^{1}$

Merek merupakan satu-satunya cara untuk menciptakan dan mempertahankan goodwill di mata konsumen di pasaran luar negeri. Merek merupakan simbol bagi pihak pedagang untuk memperluas dan mempertahankan pasarnya di luar negeri. Goodwill dari suatu produk barang atau jasa merupakan sesuatu yang tak ternilai dalam memperluas pasar. ${ }^{2}$

${ }^{1}$ Trisno Raharjo, "Analisis Terhadap Pertimbangan Hukum Hakim dalam Putusan-Putusan Perkara Merek Terkenal di Indonesia", Laporan Penelitian, Yogyakarta, UMY, 1999, hal. 1

2 Muhammad Djumhana dan R. Djubaedillah, "Hak Milik Intelektual, Teori dan Prakteknya di Indonesia",
Merek juga dapat berfungsi merangsang pertumbuhan industri dan perdagangan yang sehat, dan menguntungkan semua pihak. Diakui oleh CAFI (Commersial Advisory Foundation in Indonesia), bahwa masalah paten dan trademark di Indonesia memegang peranan yang penting dalam ekonomi Indonesia, terutama berkenaan dengan berkembangnya usaha-usaha industri dalam rangka penanaman modal.

Suatu merek dari barang atau jasa dapat diterima oleh masyarakat luas membutuhkan proses perjalanan yang panjang. Suatu perusahaan harus berupaya keras agar merek yang digunakannya dapat diterima oleh masyarakat, untuk itu upaya yang dilakukan adalah menjaga agar mutu barang atau jasa dari merek itu tetap dalam kualitas yang sesuai dengan standart, memperluas jaringan distribusi dan mampu memenuhi kebutuhan pasar. Apabila kondisi tersebut dapat dipertahankan oleh perusahaan maka merek dapat menjelma menjadi "roh" suatu produksi barang atau jasa. Sebagai "roh" produksi merek melambangkan kualitas produk, serta menjadi jaminan dan reputasi barang atau jasa dalam kegiatan perdagangan barang atau jasa sewaktu diperdagangkan. ${ }^{3}$

Lamanya waktu yang dibutuhkan untuk dapat menjadikan suatu merek menjadi terkenal secara luas dan dipergunakan oleh masyarakat luas, menjadikan beberapa produsen melakukan jalan pintas dengan menjalankan perilaku bisnis curang yaitu dengan melakukan "pembajakan" atau peniruan dari merek yang telah lama beredar di pasaran, atau dapat juga disebut sebagai merek yang sudah terkenal.

Obyek pelanggaran atau pemalsuan merek terkenal pada umumnya adalah terhadap merek-merek dagang atau jasa yang berasal dari luar negeri. Contoh, Levi's, Lea untuk produk barang jeans. Tancho untuk produk shampo, YKK, Pierre Cardin untuk produk

Citra Aditya Bakti Bandung, 1997, hal 160.

${ }^{3}$ Insan Budi Maulana, Sukses Bisnis Melalui Merek, Paten dan Hak Cipta, Citra Aditya Bakti, Bandung, 1997, hal 60 
pakaian, Bata untuk produk sepatu, Sugus untuk produk permen, Seven Up untuk produk minuman ringan, Yamaha untuk produk kendaraan motor, Revlon untuk produk kecantikan, Dunhill untuk produk parfum, Sony untuk produk elektronik.

Pelanggaran merek juga mengedepankan dalam issue pararelimport dimana barangbarang diperoleh dari luar negeri secara sah, kemudian dibawa masuk ke Indonesia untuk tujuan komersil tanpa sepengetahuan dan persetujuan pemegang lisensi atas merek tersebut di Indonesia. Dengan demikian berarti tidak ada pemalsuan merek, tetapi hal ini melanggar hak-hak penerima lisensi, karena merusak pangsa pasar pemegang lisensi.

Internet Domain Names membuka isu baru bagi perlindungan merek di Indonesia. Internet Domain Names merupakan suatu alamat di internet yang memiliki fungsi yang sama dengan merek yakni mengidentifikasi suatu perusahaan atau merek tertentu. Fakta menunjukkan bahwa banyak terjadi pendaftaran Internet Domain Names oleh pihak lain yang bukan pemilik merek yang sebenarnya. Lebih-lebih karena awalnya prinsip yang dianut untuk pendaftaran Internet Domain Names adalah first come first served. Pendaftaran oleh pihak lain yang semata-mata bertujuan untuk menjual situs tersebut kepada pemilik merek sebenarnya dengan harga yang tinggi (tanpa maksud untuk menjual produk).

Kejadian di Tanggulangin Sidoarjo khususnya yang dilakukan oleh industri tas dan koper terjadi penjiplakan dan peniruan merek secara besar-besaran terhadap merekmerek terkenal dari luar negeri untuk produk tas dan koper yang terbuat dari bahan kulit maupu bukan kulit. Contoh merek tas yang dijiplak adalah merek tas GUCCI, LOUIS VUITTON, NINA RICCI, PIERRE CARDIN, DOLCE GABANA, AITIN AIGNER, CHRISTIAN DIOR, GIANI VERSACE, VERSUS. Penjiplakan dan peniruan bukan hanya terhadap merek tetapi juga desain dan jenis bahannya sehingga sulit untuk membedakan yang asli dan yang palsu.
Penjualan terhadap produk-produk tersebut tidak dilakukan secara sembunyi-sembunyi tetapi dijual secara terbuka dalam showroomshowroom yang menarik dengan harga jauh lebih murah dibanding dengan harga merek yang asli sehingga industri tas dan koper Tanggulangin menjadi salah satu obyek wisata di Jawa Timur.

Adanya praktik curang ini, tidak hanya perusahaan pemilik merek terkenal yang dirugikan akan tetapi masyarakat sebagai konsumen dan negara juga dirugikan. Bagi pemilik merek kerugian yang dirasakan adalah menurunnya pendapatan, dan apabila kualitas dari barang dan jasa yang ditiru lebih rendah, maka akan menurunkan citra produk tersebut di mata konsumen. Bagi konsumen kerugian yang dideritanya adalah mutu barang yang rendah, sedangkan bagi negara kerugian yang timbul adalah berkurangnya penerimaan pajak.

Walaupun terhadap merek terkenal dilindungi oleh negara terbukti peraturannya mengalami beberapa kali perubahan, namun pelanggaran masih saja terjadi secara besarbesaran dan terang-terangan.

Berdasarkan latar belakang permasalahan tersebut di atas, maka dapat diambil suatu rumusan masalah sebagai berikut:

1. Mengapa produsen industri tas dan koper di desa Tanggulangin memakai merek terkenal tanpa ijin?

2. Bagaimana perlindungan hukum terhadap pemilik merek terkenal yang telah digunakan mereknya secara tanpa ijin oleh produsen industri tas dan koper di desa Tangggulangin?

\section{Tinjauan Pustaka}

Merek adalah alat untuk membedakan barang dan jasa yang diproduksi oleh suatu perusahaan. Menurut pasal 1 ayat (1) Undangundang Nomor 15 tahun 2001 tentang Merek, dinyatakan bahwa "merek adalah tanda yang berupa gambar, nama, kata, huruf-huruf, angka-angka, susunan warna, atau kombinasi 
dari unsur-unsur tersebut yang memiliki daya pembeda dan digunakan dalam kegiatan perdagangan barang dan jasa".

Berdasarkan ketentuan tersebut ada beberapa unsur dalam merek, yaitu:

a. Tanda

b. Memiliki daya pembeda

c. Digunakan untuk perdagangan barang dan atau jasa

Sebuah merek dapat disebut merek apabila memenuhi syarat muntlak berupa adanya daya pembeda yang cukup (capable of distinguishing). Maksudnya tanda yang dipakai (sign) tersebut memiliki kekuatan untuk membedakan barang atau jasa yang diproduksi suatu perusahaan dari perusahaan lainnya. Untuk mempunyai daya pembeda ini, maka merek itu harus dapat memberikan penentuan atau "individualishing" pada barang atau jasa yang bersangkutan. ${ }^{4}$

Tanda-tanda yang dapat dijadikan merek jika secara konvensional berupa gambar, nama, kata-kata, huruf-huruf, angka-angka atau kombinasinya, dalam perkembangannya kini mencakup:

a. Aroma (scent)

Contoh: parfum, kartu HALMARCK

b. Suara (sound)

Contoh: nada panggil siaran BBC, deru motor besar HARLEY DAVIDSON

c. Warna (colour)

Contoh: Kodak

d. Tanda tangan (signature)

Contoh: Kantor Firma Hukum (nama Firma diambil dari firmant-firmantnya)

e. Bentuk (shape)

Contoh: Botol Coca-Cola Persyaratan daya pembeda (distinctiveness) merupakan persyaratan materiil agar suatu tanda dapat dilindungi sebagai suatu merek. ${ }^{5}$

\footnotetext{
${ }^{4}$ Muhammad Djumhana dan R. Djubaedillah, Hak Milik Intelektual, Sejarah, teori, dan Praktetenya di Indonesia, Citra Aditya Bakti, Bandung, 1997, hal 156

${ }^{5}$ Rahmi Jened, "Perlindungan Merek di Indonesia", Pelatiban HAKI VI bagi para Dosen Perguruan Tinggi
}

Indonesia memberikan perlindungan terhadap merek terdaftar yang pendaftarannya dilandasi itikad baik (tegoede trow atau good faith). Sistem pendaftaran di Indonesia menganut system konstitutif sebagaimana tertuang dalam pasal 3 yang menyatakan bahwa Hak atas Merek adalah hak eksklusif yang diberikan oleh negara kepada pemilik merek yang terdaftar dalam Daftar Umum Merek untuk jangka waktu tertentu dengan menggunakan sendiri merek tersebut atau memberi ijin kepada pihak lain untuk menggunakannya", artinya. Bagi orang yang mendaftarkan mereknya mendapat suatu kepastian hukum bahwa dialah yang berhak atas merek. Sebaliknya bagi pihak lain yang mencoba akan mempergunakan merek yang sama atas barang atau jasa lainnya yang sejenis, oleh Kantor Merek akan ditolak pendaftarannya. Pendaftaran merek harus memenuhi persyaratan materiil dan formil. Undang-undang Nomor 15 tahun 2001 menetapkan bahwa persyaratan materil ditentukan dalam pasal 4, 5, dan 6 .

Pasal 4 menyatakan merek tidak dapat didaftar atas dasar permohonan yang diajukan oleh pemohon yang beritikad tidak baik. Pemohon yang beritikad baik adalah pemohon yang mendaftarkan mereknya secara layak dan jujur tanpa ada niat membonceng, meniru atau menjiplak ketenaran pihak lain demi usahanya yang berakibat kerugian pada pihak lain atau menimbulkan kondisi persaingan curang, mengecoh atau menyesatkan konsumen.

Pasal 5 menyatakan merek tidak dapat didaftar apabila merek tersebut mengandung salah satu unsur di bawah ini:

a. Bertentangandenganperaturanperundangundangan yang berlaku, moralitas agama, kesusilaan, ketertiban umum. Termasuk dalam pengertian bertentangan dengan moralitas agama, kesusilaan, atau ketertiban umum adalah apabila penggunaan tanda tersebut dapat menyinggung perasaan,

Indonesia Timur, Fakultas Hukum Universitas Airlangga kerjasama dengan Perhimpunan Masyarakat HAKI Indonesia, Surabaya, 27 Agustus-8 Desember 2001, hal 4 
kesopanan, ketentraman, atau keagamaan dari khalayak umum atau dari golongan masyarakat tertentu.

b. Tidak memiliki daya pembeda. Tanda dianggap tidak memiliki daya pembeda apabila tanda tersebut terlalu sederhana, seperti satu tanda garis atau satu tanda titik, ataupun terlalu rumit sehingga tidak jelas

c. Telah menjadi milik umum. Salah satu contoh merek seperti ini adalah tanda tengkorak diatas dua tulang yang bersilang, yang secara umum telah diketahui sebagai tanda bahaya. Tanda seperti itu adalah tanda yang bersifat umum dan telah menjadi milik umum. Oleh karena itu tanda semacam itu tidak dapat digunakan sebagai merek

d. Merupakan keterangan atau berkaitan dengan barang atau jasa yang dimohon pendaftarannya. Merek tersebut berkaitan atau hanya menyebutkan barang atau jasa yang dimohonkan pendaftarannya, contohnya: merek kopi atau gambar kopi untuk jenis barang kopi atau untuk produk kopi.

Pasal 6 ayat (1) menyatakan permohonan harus ditolak oleh Direktorat Jenderal apabila merek tersebut:

1. Mempunyai persamaan pada pokoknya atau keseluruhannya dengan merek milik pihak lain yang sudah terdaftar lebih dahulu untuk barang dan atau jasa yang sejenis

2. Mempunyai persamaan pada pokoknya atau keseluruhannya dengan merek yang sudah terkenal milik pihak lain untuk barang dan atau jasa yang sejenis.

3. Mempunyai persamaan pada pokoknya atau keseluruhannya dengan merek dengan indikasi geografis yang sudah dikenal

Ketentuan bahwa persamaan pada pokoknya dapat pula diberlakukan terhadap barang dan jasa yang tidak sejenis sepanjang memenuhi persyaratan yang ditetapkan dalam Peraturan Pemerintah.

Permohonan juga harus ditolak oleh
Direktorat Jenderal apabila merek tersebut:

1. Merupakan atau menyerupai nama orang terkenal, foto atau nama badan hukum yang dimiliki orang lain, kecuali atas persetujuan tertulis dari yang berhak.

2. Merupakan tiruan atau menyerupai nama atau singkatan nama, bendera, lambing, atau simbol atau emblem negara, atau lembaga nasional maupun lembaga international, kecuali atas persetujuan tertulis dari pihak yang berwenang.

3. Merupakan tiruan atau merupakan tanda atau cap atau stempel resmi yang digunakan oleh negara atau lambing pemerintah, kecuali atas persetujuan tertulis dari pihak yang berwenang.

Hak khusus memakai merek ini yang berfungsi seperti suatu monopoli hanya berlaku untuk barang atau jasa tertentu. Oleh karena suatu merek memberi hak khusus atau hak mutlak kepada yang bersangkutan, maka hak itu dapat dipertahankan terhadap siapapun.

Berdasarkan reputasi dan kemashurannya, suatu merek dapat dibedakan menjadi tiga jenis, merek biasa (normal marks), merek terkenal (well known marks), dan merek termashur (famous marks) ${ }^{6}$.

Merek biasa adalah merek yang tergolong tidak memiliki reputasi tinggi, ciri-cirinya adalah kurang memberi pancaran simbol gaya hidup, masyarakat konsumen sering menilai sebagai barang atau jasa berkualitas rendah, merek sering dianggap tidak mempunyai drawing power yang mampu memberi sentuhan keakraban dan kekuatan mitos yang sugestif kepada masyarakat konsumen, dan tidak membentuk lapisan pasar dan pemakai. ${ }^{7}$

Merek terkenal adalah merek yang memiliki

${ }^{6}$ Ridwan Khairandy, " Perlindungan Hukum Merek Terkenal di Indonesia”, Seminar Nasional Perlindungan Hukum Merek dalam Era Persaingan Pasar Global, Fakultas Hukum Universitas Islam Indonesia, Yogyakarta, 1999, hal 4

${ }^{7}$ M Yahya Harahap, Tinjauan Merek secara Umum dan Hukum Merek di Indonesia Berdasarkan Undang-undang No.19 Tabun 1992, Citra Aditya Bakti, Bandung,, 1996, hal 80-81 
reputasi tinggi, karena memiliki kekuatan pancaran yang memukau dan menarik, sehingga jenis barang apa saja yang berada dibawah merek itu langsung memberikan sentuhan keakraban dan sentuhan mitos kepada segala lapisan konsumen. ${ }^{8}$

Merek termashur, yaitu merek yang karena perkembangannya telah dikenal secara luas di seluruh dunia, dan memiliki reputasi yang dapat digolongkan sebagai "merek aristokrat dunia".

Antara merek terkenal dan merek termashur terdapat persamaan-persamaan kriteria sehingga semua konvensi-konvensi international dan peraturan perudangundangan nasional di bidang merek pada dasarnya hanya mengenal merek biasa dan merek terkenal.

Kasus-kasus pelanggaran merek terkenal yang terjadi di Indonesia dapat dijumpai dari pedagang kaki lima di sepanjang trotoar pusat-pusat perbelanjaan sampai pusat-pusat pertokoan yang berada di mal-mal mewah yang memajang barang-barang dagangannya di etalase yang indah.

Pelanggaran merek terkenal dilakukan sebagai jalan pintas perusahaan atau orangperorangan yang beritikad tidak baik dengan memakai merek-merek terkenal itu untuk produk yang dihasilkan dengan maksud memperoleh keuntungan finansial yang besar. Hal itu melanggar prinsip-prinsip perlindungan hak atas kekayaan intelektual. Merek adalah salah satunya yang menekankan pada pentingnya perlindungan suatu hak yang dapat dieksploitasi secara ekonomis.

Perlindungan hukum yang memadai terhadap merek-merek terkenal, yang kebanyakan adalah merek terkenal dari luar negeri muntlak diperlukan, tanpa mengurangi hak pengusaha pribumi yang memiliki merek yang sama dengan merek terkenal tersebutyang menggunakannya dengan itikad baik. Namun demikian untuk menjaga keseimbangan hak dari pemilik merek terkenal dalam dan luar

\footnotetext{
${ }^{8}$ Ibid, hal 82-82

${ }^{9}$ Ibid, hal 85
}

negeri, perlu juga kiranya dirumuskan kriteria merek terkenal "lokal", yaitu merek terkenal yang berkembang pada suatu daerah atau wilayah tertentu atau merek terkenal yang berada dalam suatu negara. ${ }^{10}$

\section{Tujuan Penelitian}

Tujuan penelitian ini diharapkan dapat menggambarkan berbagai hal yang berhubungan dengan permasalahan dalam penelitian ini, yaitu untuk mengetahui serta mengkaji:

a. Alasan produsen Industri Tas dan Koper di Desa Tanggulangin menggunakan merekmerek terkenal tanpa ijin.

b. Bentuk perlindungan hukum terhadap pemilik merek terkenal yang telah digunakan mereknya secara tanpa ijin oleh produsen Industri Tas dan Koper di Desa tanggulangin

\section{Pembahasan}

\section{Pelanggaran Merek Terkenal di Industri Tas dan Koper di Tanggulangin}

Perlindungan merek terkenal merupakan salah satu aspek penting dari hukum merek. Kepentingan ekonomi dari merekmerek terkenal diakui dalam Bab XX perjanjian internasional WIPO. Dalam perkembangannyanmerek-merekterkenaljuga diakui di Amerika Serikat, Inggris, Australia dan oleh Pasal 6 ayat (1) huruf b Undangundang Merek Indonesia, yaitu "permohonan harus ditolak oleh Direktorat Jenderal apabila Merek tersebut mempunyai persamaan pada pokoknya atau keseluruhannya dengan Merek yang sudah terkenal milik pihak lain untuk barang dan atau jasa yang sejenis."

Salah satu ciri utama dari merek terkenal adalah bahwa reputasi merek tidak harus terbatas pada produk tertentu atau jenis produk. Contohnya Marlboro adalah merek yang diasosiasikan dengan produk-produk tembakau. Ternyata, merek tersebut juga dipakai untuk pakaian. Para konsumen dapat

\footnotetext{
${ }^{10}$ Trisno Raharjo, op. cit, hal 18
} 
menyaksikan bahwa hampir seluruh jenis barang yang tidak berhubungan dengan merek terkenal telah dieksploitasi untuk jenis barang dan jasa yang berbeda. Kecenderungan yang sama juga muncul pada merek-merek seperti Porsche dan Caterpillar.

Ciri dari merek terkenal adalah bahwa perlindungan diberikan dalam hubungan pemakaian secara umum dan tidak hanya berhubungan dengan jenis barang-barang dimana merek tersebut didaftarkan. Perlindungan ini dijamin dalam Pasal 6 ayat(2) undang-undang Merek. Perlindungan yang diberikan oleh Undang-undang Merek terhadap merek terkenal merupakan pengakuan terhadap keberhasilan pemilik merek dalam menciptakan citra (image) eksklusif dari produknya yang diperoleh melalui pengiklanan atau penjualan produkproduknya secara langsung.

Teori pencemaran merek terkenal (dilution theory) tidak mensyaratkan adanya bukti telah terjadi kekeliruan dalam menilai sebuah pelanggaran merek terkenal. Perlindungan didasarkan pada nilai komersial atau nilai jual dari merek dengan cara melarang pemakaian yang dapat mencemarkan nilai eksklusif dari merek atau menodai daya tarik merek terkenal tersebut.

Para pelaku dagang berkepentingan untuk melindung produknya melalui perundangundangan terhadap pelanggaran merek atau mengubah barang atau jasa mereka menjadi sesuatu yang lebih berharga dengan lisensi dan penyerahan hak. Salah satu kesulitan yang muncul dari ketentuan Undang-undang Merek tersebut adalah tidak adanya pedoman yang jelas untuk menentukan kriteria merek terkenal. ${ }^{11}$

Praktek perdagangan di Indonesia, mulai pedagang kaki lima hingga di pertokoan besar banyak ditemui berbagai macam produk merek terkenal seperti Levi's, Yves Saint Laurent, Valino, Tira, Guy, Pierre Cardin, Lea, Arrow, Versace.

Penggunaan merek terkenal untuk produk

\footnotetext{
${ }^{11}$ Tim Lindsey, at.al., op. cit., hal 149-151
}

tas dan koper tidak hanya ditemui di emperanemperan toko dan plaza-plaza tetapi dapat kita temui juga di desa Tanggulangin yang terletak di kabupaten Sidoarjo Jawa Timur. Desa tersebut merupakan sentra industri yang memproduk tas dan koper yang dikenal dengan INTAKO (Industri Tas dan Koper) dan dibina oleh sebuah koperasi yang diberi nama koperasi intako. Intako memproduksi tas dan koper dari bahan plastic, imitasi kulit sampai dengan kulit yang asli. Produk tas dan koper dari Intako tersebut diberi label merek-merek asing yang sudah terkenal seperti: GUCCI, LOUIS VUITTION, NINA RICCI, PIERE CARDIN, DOLCE GABANA, AITIN AIGNER, CALVIN KLEIN, CHRISTIAN DIOR, GIANI VERSACE, VERSUS, CHARLES JORDAN, ELISABETH. Hasil produksi tersebut dipamerkan di ruang pamer sepanjang jalan di desa Tanggul Angin yang menjadi salah satu objek wisata yang menarik di Jawa Timur.

Harga penjualan dari produk tersebut sangat bervariasi dari harga yang sangat murah Rp 10.000 untuk bahan yang terbuat dari jenis plastik sampai dengan harga $\mathrm{Rp}$ 750.000 untuk bahan yang terbuat dari jenis kulit asli (bahan, model dan merek sama persis dengan yang asli). Harga tersebut jauh lebih murah dibandingkan dengan harga tas dengan bahan dan merek yang asli. Produksi dari Intako Tanggulangin ini tidak hanya dijual di wilayah Sidoarjo atau jawa Timur tetapi sudah ke daerah-daerah lain di Indonesia bahkan sampai luar negeri. Untuk tas raket perusahaan raket di Jepang misalnya adalah hasil Intako Tanggulangin. Begitu juga dengan negara-negara tetangga lainnya.

Pemakaian merek terkenal oleh Intako di Tanggulangin merupakan pelanggaran merek secara besar-besaran, yang mengundang perhatian dari masyarakat internasional terutama dari negara Eropa. Karena merek yang dipakai oleh Intako tanpa melalui suatu perjanjian lisensi dengan pemilik merek yang asli atau orang yang ditunjuk untuk itu. Sebab itu industri tas dan koper yang menggunakan 
merek-merek terkenal berjalan terus seakan tak ada persoalan hukum atas apa yang mereka lakukan. Teguran yang sifatnya lunak maupun keras dari Eropa telah dilakukan berulang-ulang. Mereka mengancam kalau pelanggaran terus dilakukan maka mereka akan memutus hubungan perdagangan dengan negara Indonesia. Di satu sisi produksi yang dilakukan oleh Intako di Tanggulangin telah mampu meningkatkan perekonomian di desa Tanggulangin khususnya dan Jawa Timur umumnya karena banyaknya peminat terhadap produk tersebut bahkan telah menjadi salah satu kota wisata di Jawa Timur yang diminati bukan hanya oleh masyarakat biasa, para kaum selebritis maupun pejabat daerah dan pejabat pusat merupakan konsumen dari Intako, maka Gubernur Jatim pada mohon kepada departemen hak merek untuk memberi waktu kepada pengusaha Industri Tas dan Koper di Tanggulangin agar produknya tidak ditarik secara tiba-tiba dan membiarkan industri merekatetapberjalansebagaimanasebelumnya tetapi secara perlahan mereka harus sudah mencoba membuat merek sendiri. Sedangkan pada industri Tas dan Koper di Tanggulangin saat ini ada 2 perusahaan yang sudah memiliki merek sendiri yaitu, Viola dan Ch (Choiri).

Alasan Intako menggunakan merek-merek yang sudah terkenal, menurut pemilik toko MITRA JAYA dan SUMBER MAKMUR, produknya sangat diminatioleh ibu-ibu pejabat daerah maupun pusat serta para selebritis. Di tokonya konsumen lebih memilih tas yang menyamai merek-merek asing daripada merek buatan sendiri terutama merek Aitin Aigner (A) dan Calvin Clein (CC), apalagi kalau bahan dan modelnya dibuat sama persis dengan aslinya pasti banyak peminatnya. Harga dari produk tersebut antara Rp 300.000,00 sampai dengan $\mathrm{Rp} 750.000,00$.

Menurut pemilik toko Melati, toko Cahaya, toko Indah, toko Mentari, toko Sinar untuk produk tas dan dompet yang dijual mulai harga Rp 10.000,00 sampai dengan harga Rp 200.000,00 diminati konsumen bukan karena merek tetapi karena modelnya sedangkan untuk produk tas dan dompet yang seharga Rp 250.000,00 keatas bagi konsumen merek sangat menentukan untuk dijadikan pilihan.

Permasalahan pelanggaran dan perlindungan hukum terhadap merek terkenal sebenarnya bukan masalah baru. Konvensi Paris sendiri melalui amandemennya dalam konferensi di Den Haag pada tahun 1925 telah memasukkan Pasal 6 bis yang ditujukan untuk memberikan perlindungan hukum merek terkenal ${ }^{12}$. Seiring dengan telah diratifikasinya konvensi Pembentukan Perdagangan dunia atau WTO yang didalamnya antara lain memuat ketentuan Trade Related Aspects of Intellectual Property Right (TRIPs). Untuk lebih memberikan kepastian hukum dan perlindungan hukum terhadap pemilik merek, pemerintah telah membaharui hukum merek dari Undang-undang Nomor 14 Tahun 1997 dengan Undang-undang Nomor 15 Tahun 2001.

Suatu merek dianggap mempunyai persamaan pada pokoknya dengan merek orang lain ditentukan berdasarkan patokan yang lebih lentur disbanding dengan doktrin entires similar. Persamaan pada pokoknya dianggap terwujud apabila merek tersebut memiliki kemiripan (identical) dengan merek orang lain. Kemiripan tersebut dapat didasarkan pada:

1. kemiripan persamaan gambar;

2. hampir mirip atau hampir sama susunan kata, warna, atau bunyi;

3. faktor yang paling penting dalam doktrin ini, pemakaian merek menimbulkan kebingungan (actual confusion) atau menyesatkan (device) masyarakat konsumen. Seolah-olah merek tersebut dianggap sama sumber produksi dan sumber asal geografis dengan barang milik orang lain (likelihood confusion). ${ }^{13}$

Pelanggaran merek yang terjadi di sentra Industri tas dan koper di Tanggulangin Sidoarjo adalah masuk dalam kategori persamaan jenis atau produksi kelas barang

\footnotetext{
${ }^{12}$ Ridwan Khairandy, "Kapita...”, op. cit., hal 112

${ }^{13}$ Ibid., hal 117-118
} 
atau jasa dan kategori hampir mirip atau sama susunan kata, warna, atau bunyi.

\section{Upaya Hukum Perlindungan Merek}

Reputasi atau itikad baik dalam dunia bisnis dipandang sebagai kunci sukses atau kegagalan dari sebuah perusahaan. Banyak pelaku usaha berjuang untuk mendapatkan dan menjaga reputasi mereka dengan mempertahankan kualitas produk dan memberikan jasa kelas satu kepada para konsumen. Kalangan pelaku usaha mengeluarkan uang dalam jumlah yang besar untuk keperluan periklanan dan membangun reputasi produk baru atau mempertahankan reputasi dari produk yang telah ada.

Robert S Smith mengemukakan teori berkaitan dengan jaminan perlindungan merek dan barang produksinya. ${ }^{14}$ Suatu merek menyajikan fungsi perlindungan sebagai investasi dari pemilik merek dengan itikad baik, dan melayani konsumen dengan suatu tanda yang mudah dari sumber dan kualitas barang produksi dari label merek itu. Jaminan keaslian barang produksi dari pemilik merek yang beritikad baik merupakan suatu promosi untuk menghilangkan keraguan dari konsumen. Dengan demikian, perlindungan merek menjadi fungsi utama dan sekaligus melindungi konsumen dari membeli barang palsu.

William Jay Gross menyatakan, basis dari suatu merek mempunyai fungsi untuk memberi keuntungan kepada perusahaan dan konsumen. Keuntungan perusahaan diperoleh dari keunggulan kompetisi dan meningkatkan keuntungan berdasarkan investasi merek yang diciptakan. Di sisi lain, keuntungan konsumen diperoleh dari hasil merek yang menginformasikan produk dan dukungan perusahaan yang memproduksi barang-barang berkualitas. Dengan demikian, hukum merek memberikan perlindungan kepada konsumen dan perusahaan terhadap

14 Effendy Hasibuan, Perlindungan Merek Studi Putusan Pengadilan Indonesia dan Amerika Serikat, Jakarta, Fakultas Hukum Universitas Indonesia, 2003, hal 18 pemalsuan merek. ${ }^{15}$

Pemakaian merek atas barang-barang produksi bertujuan untuk melindungi masyarakat konsumen dari bujukan yang dilakukan pesaing atau pemalsu merek. Produsen barang memakai simbol merek untuk promosi dalam rangka memperoleh simpatikonsumen. Karena loyalitas konsumen terhadap suatu simbol merek merupakan bagian dari itikad baik bisnis. ${ }^{16}$

Hukum melindungi orang-orang yang memiliki reputasi dari orang-orang yang ingin "membonceng" kesuksesan mereka. Meskipun reputasi tersebut adalah sesuatu yang tidak berwujud, hukum memandangnya sebagai asset berharga yang harus dilindungi. Kompetitor atau pelaku usaha lain tidak dapat menggunakan merek-merek, tulisan-tulisan, kesan atau indikasi lain yang akan mendorong pembeli meyakini bahwa barang-barang yang dijual mereka diproduksi oleh orang lain.

Pemilik merek dapat mengajukan gugatan ganti rugi maupun tuntutan hukum pidana melalui aparat penegak hukum. Pemilik merek terdaftar juga memiliki hak untuk mengajukan permohonan pembatalan pendaftaran merek terhadap merek yang sama yang didaftarkan orang lain secara tanpa hak. Perlindungan hukum yang represif ini diberikan apabila telah terjadi pelanggaran hak atas merek. Di sini peran lembaga peradilan dan aparat penegak hukum lainnya, seperti kepolisian, Penyidik Pegawai Negeri Sipil (PPNS), dan kejaksaan sangat diperlukan. ${ }^{17}$

Pemilik merek terdaftar atau penerima Lisensi Merek terdaftar dapat mengajukan gugatan melalui Pengadilan Niaga di wilayah hukum tempat tinggal atau domisili tergugat, terhadap pihak lain yang secara tanpa hak menggunakan merek yang mempunyai persamaan pada pokoknya atau keseluruhannya untuk barang atau jasa yang sejenis berupa:

1. Gugatan rugi dan atau

\footnotetext{
${ }^{15}$ Ibid., hal 19

${ }^{16}$ Ibid

${ }^{17}$ Ibid., hal 105
} 
2. Penghentian semua perbuatan yang berkaitan dengan penggunaan merek tersebut.

Berdasarkan bukti yang cukup pihak penggugat, dengan mengajukan secara tertulis dapat meminta kepada hakim Pengadilan Niaga untuk menerbitkan surat penetapan sementara tentang penyimpanan alat bukti yang berkaitan dengan pelanggaran tersebut dengan persyaratan:

1. Melampirkan bukti kepemilikan

2. Melampirkan bukti adanya petunjuk awal yang kuat atas terjadinya pelanggaran merek.

Selama masih dalam pemeriksaan dan untuk mencegah kerugian yang lebih besar, atas permohonan pemilik merek atau penerima lisensi selaku penggugat, hakim dapat memerintahkan tergugat untuk menghentikan produksi, pengedaran atau perdagangan barang atau jasa yang menggunakan merek tersebut secara tanpa hak. Dalam hal tergugat dituntut juga menyerahkan barang yang menggunakan merek secara tanpa hak, hakim dapat memerintahkan bahwa penyerahan barang atau nilai barang tersebut dilaksanakan setelah putusan pengadilan mempunyai kekuatan hukum tetap.

Penggugat juga harus menunjukkan bahwa representasi yang menyesatkan dari tergugat telah menyebabkan kerugian nyata dan kerugian tersebut akan terus berlanjut jika aktifitas tergugat diteruskan. Penggugat dapat mengalami kerugian dalam tiga bentuk:

1. Penggugat dapat menunjukkan bahwa bisnisnya sudah menderita kerugian atau secara potensial menderita kerugian baik dalam itikad baik maupun dalam reputasi bisnisnya. Penurunan itikad baik dapat disebabkan oleh diversi perdagangan tergugat sebagai akibat dari anggapan keliru tergugat yang menciptakan kesan palsu seolah-olah barang-barang atau jasa-jasa dari penggugat maupun tergugat adalah sama atau mempunyai karakter yang sama. Penggugat juga dapat menderita kerugian melalui "pencemaran" reputasinya dimana anggapan yang keliru atas produk tergugat mengurangi kesan eksklusif atau reputasi dari produk penggugat.

2. Penggugat dapat menunjukkan bahwa tergugat merusak potensi penggugat untuk mempergunakan itikad baiknya di masa yang akan datang

3. Penggugat telah kehilangan kesempatan untuk mengembangkan usahanya di bidang lain

Penyelesaian pelanggaran merek selain melalui proses Pengadilan Niaga para pihak dapat menyelesaikan sengketa melalui Arbitrase atau Alternatif Penyelesaian Sengketa.

Pemilik merek terdaftar selain mendapat perlindungan hukum secara perdata juga mendapat perlindungan hukum secara pidana. Dan hak untuk mengajukan gugatan secara perdata tidak akan mengurangi hak negara untuk melakukan tuntutan tindak pidana di bidang merek. Karena sifat dari tindak pidana tersebut adalah delik aduan maka setiap orang yang memiliki merek terdaftar dan haknya dirugikan dapat melaporkan pihak yang melakukan pelanggaran terhadap merek miliknya kepada polisi, yang disertai dengan bukti hak atas merek tersebut dan polisi akan melakukan tindakan terhadap terlapor setelah mendapatkan laporan dari pemilik merek.

Pasal 90 dan 91 Undang-undang Merek menegaskan, barang siapa sengaja secara tanpa hak menggunakan merek yang sama pada keseluruhannya dengan merek terdaftar milik pihak lain untuk barang dan atau jasa yang sejenis yang diproduksi dan atau diperdagangkan, di pidana dengan pidana penjara paling lama 5 (lima) tahun dan atau denda paling banyak Rp1.000.000.000,00 (satu milyar rupiah). Sedangkan jika secara tanpa hak menggunakan merek yang sama pada pokoknya dengan merek terdaftar milik pihak lain, dipidana dengan penjara paling lama 4 (empat) tahun dan atau denda paling banyak Rp.800.000.000,00 (delapan ratus juta rupuah). 
Perlindungan preventif dan represif yang diberikan oleh negara adalah untuk mencegah oreang lain melakukan dua hal:

1. Menampilkan atau menyebabkan anggapan bahwa barang yang diproduksi adalah barang orang lain, dan

2. Menimbulkan anggapan bahwa barang ada hubungannya dengan barang penggugat.

Di Pengadilan Niaga Surabaya belum ada kasus yang diajukan oleh pemilik merek terkenal dari negara asing, seperti GUCCI, LOUIS VUITTON, NINA RICCI, PIERRE CARDIN, DOLCE GABANA, AITIN AIGNER, CHRISTIAN DIOR, GIANI VERSACE, VERSUS,CHARLES JORDAN, ELISABETH maupun merekmerek yang lain, untuk produk tas yang ditiru oleh sentra industri tas dan koper di Tanggulangin Sidoarjo.

Ketua Koperasi Intako menyatakan bahwa, memang sampai saat ini belum ada kasus gugatan yang diajukan kepada anggotanya sehubungan dengan penggunaan merek terkenal yang dijiplak oleh industri tas dan koper di Tanggulangin. Tetapi kalau teguran dari pemerintah Eropa melalui pemerintah Indonesia pernah mereka terima. Dan melalui Gubernur Jawa Timur para produsen di sentra industri Tanggulangin mohon tetap diperkenankan menggunakan merek-merek terkenal dari negara asing apalagi produk yang mereka buat baik model maupun bahannya dibuat dengan model yang sederhana dan berbeda dengan aslinya begitu juga dengan bahan yang digunakan, dan masyarakat mengetahui bahwa produk yang dibeli adalah produksi Tanggulangin. Sesungguhnya konsumen membeli tas di Intako bukan semata-mata tertarik pada mereknya tetapi unsur utama yang membuat konsumen tertarik adalah harga dan desainnya serta bahannya. Buktinya ketika pengrajin membuat tas yang modelnya sama dengan merek terkenal tetapi mereknya berbeda dari aslinya ternyata samasama diminati oleh konsumen. Oleh karena itu Dinas Perindustrian dan Perdagangan Sidoarjo dan Gubernur Jawa Timur melalui Dirjen
Hak Kekayaan Intelektual meminta kepada pemilik merek negara luar untuk sementara waktu mentolerir penggunaan merek-merek terkenal milik mereka yang pada suatu saat Intako akan menggunakan mereknya sendiri apalagi kegiatan sentra industri tas dan koper di Tanggulangin sangat mengangkat tingkat perekonomian masyarakat Tanggulangin khususnya dan Sidoarjo umumnya.

\section{Kesimpulan dan Saran}

\section{Kesimpulan}

Persoalan perlindungan hukum terhadap pemilik merek terkenal tidak hanya dapat dipandang dari aspek hukum saja, tetapi perlu pula dipandang dari aspek ekonomi dan sosial yang terdapat dalam masyarakat, termasuk pula faktor yang mengakibatkan terjadinya sengketa "merek terkenal", antara lain:

1. Kemampuan bersaing antara pemilik merek terkenal dengan beberapa pengusaha lokal atau "mereka" yang dianggap melakukan pelanggaran terhadap pemilik merek terkenal (asing) terjadi karena terdapat faktor-faktor yang tidak seimbang. Ketidakseimbangan terjadi karena kemampuan modal (sehingga pemilik merek terkenal dapat mendaftarkan mereknya ke berbagai negara), dan sumber daya manusia yang meliputi pula kemampuan untuk melakukan promosi, pemasaran, serta persaingan yang jujur. Hal tersebut terjadi pula di sentra industri tas dan koper Tanggulangin. Di sisi lain sikap "bangga" masyarakat konsumen ketika memilih dan memakai produkproduk dengan merek terkenal serta rasa tidak percaya diri terhadap produk dalam negeri juga menjadi salah satu alasan kenapa produsen industri tas dan koper Tanggulangin memakai merek terkenal untuk produk yang dihasilkan.

2. Dilihat dari substansi Undang-undang Merek, perlindungan hukum terhadap pemilik merek terkenal di Indonesia telah cukup memadai, namun pelanggaran 
terhadap merek terkenal tetap berlangsung, termasuk di lokasi penelitian, yaitu Desa Tanggulangin, Sidoarjo, Jawa Timur.

\section{Saran}

1. Perlindungan hukum terhadap merek terkenal terutama harus didukung oleh produsen itu sendiri karena bagi konsumen dalam membeli tas produk Intako sematamata bukan tertarik pada mereknya tetapi pada model dan harganya yang cukup murah.

2. Pihak Pemerintah Daerah Tingkat II dan Pemerintah Daerah Tingkat I seharusnya menyadari bahwa walaupun ingin meningkatkan taraf perekonomian masyarakat Jawa Timur khususnya masyarakat Sidoarjo, perlindungan hukum terhadap merek terkenal tetap harus dilindungi dan didukung sesuai dengan program yang dibuat oleh negara dengan beberapa kali merubah peraturan perundang-undangan tentang merek, apalagi menyangkut nama baik bangsa Indonesia di mata international agar tidak menyandang gelar sebagai negara penjiplak merek terkenal.

\section{Daftar Rujukan}

Effendy Hasibuan, Perlindungan Merek Studi Putusan Pengadilan Indonesia dan Amerika Serikat, Jakarta, Fakultas Hukum Universitas Indonesia, 2003

Insan Budi Maulana, Sukses Bisnis Melalui Merek, Paten dan Hak Cipta, Citra Aditya Bakti, Bandung, 1997

\section{Perlindungan Merek.}

Terkenal di Indonesia dari Masa ke masa, Citra Aditya Bakti, Bandung, 1999

M Yahya Harahap, Tinjauan Merek secara Umum dan Hukum Merek di Indonesia Berdasarkan Undang-undang No.19 Tabun 1992, Citra Aditya Bakti, Bandung, 1996

Muhammad Djumhana dan R. Djubaedillah, "Hak Milike Intelektual, Teori dan Prakteknya di Indonesia", Citra Aditya
Bakti Bandung, 1997

Rahmi Jened, “Implikasi Persetujuan TRIP’s terhadap Perlindungan Merek di Indonesia, Yuridika, 2000

"Perlindungan Merek di Indonesia", Pelatiban HAKI VI bagipara Dosen Perguruan Tinggi Indonesia Timur, Fakultas Hukum Universitas Airlangga kerjasama dengan Perhimpunan Masyarakat HAKI Indonesia, Surabaya, 27 Agustus-8 Desember 2001

Ridwan Khairandi, " Perlindungan Hukum Merek Terkenal di Indonesia", Seminar NasionalPerlindungan Hukum Merek dalam Era Persaingan Pasar Global, Fakultas Hukum Universitas Islam Indonesia, Yogyakarta, 1999

Tim Lindsey, Hake Kekayaan Intelektual suatu pengantar, Asian Law Group Ltd ekerjasama dengan PT Alumni Bandung, 2002,hal 139-140

Trisno Raharjo, "Analisis Terhadap Pertimbangan Hukum Hakim dalam Putusan-Putusan Perkara Merek Terkenal di Indonesia", Laporan Penelitian, Yogyakarta, UMY, 1999 